\title{
The evolution of ultraviolet patterns in European Colias butterflies (Lepidoptera, Pieridae): a phylogeny using mitochondrial DNA
}

\author{
CLAIR F. A. BRUNTON* \\ Department of Genetics, Downing Street, Cambridge, CB2 3EH, U.K.
}

\begin{abstract}
Ultraviolet patterns in butterflies have been recognized and studied for many years and are thought to be involved in species recognition and sexual selection. Recent hypotheses state that sexually selected traits may be subject to relatively fast continual change over time. As a result, closely related species can differ markedly in sexual traits but hardly at all in nonsexual morphology. A molecular phylogeny of European Colias is reconstructed, not only to elucidate patterns of colonization and spread, but also to show whether those species with or without UV patterns constitute two monophyletic groups, or, as might be expected from the hypothesis, they are polyphyletic. The phylogeny indicates that the European species form three monophyletic clades corresponding broadly to their geographical distributions. The Scandinavian species appear to be the oldest in Europe and last shared a common ancestor with those from the USA. From Scandinavia they have radiated to the rest of Europe forming an eastern clade and a western clade. The presence of UV is polyphyletic within the whole group (and within each clade), consistent with the hypothesis that UV is a trait under intra- and/or interspecific selection.
\end{abstract}

Keywords: cytochrome oxidase I, mitochondrial DNA, phylogeny, sexual selection, systematics, ultraviolet patterns.

\section{Introduction}

Ever since the 1930s ultraviolet patterns have been recognized and studied in insects (Lutz, 1932), but one group which has received more attention than most is the Lepidoptera. This is probably because colour in general (both visible and ultraviolet) is particularly spectacular in butterflies, and its amenity to study has meant that much work has been devoted to discovering the functions and reasons for the huge diversity of patterns.

Although humans are blind to the short wavelengths $(<400 \mathrm{~nm})$ characteristic of UV light, most insects (Menzel \& Backhaus, 1990), many birds (Burkhardt, 1988; Bennett et al., 1995), reptiles (Fleishman et al., 1992) and some mammals (Jacobs, 1991) can see UV light. As such, UV colours in these animals are no less important than 'visible'

\footnotetext{
*Correspondence: Department of Biology and Biochemistry, University of Bath, Claverton Down, Bath BA2 7AY, U.K. E-mail: bsscab@bath.ac.uk
}

colours and their function is likely to be similar. Their invisibility to humans, however, has meant that, in the past, less experimental work was carried out on UV patterns and their potential existence in most animals was largely ignored (Bennett et al., 1993). The possible exception to this general trend was the Lepidoptera and a great deal of work has been carried out since the 1950s, particularly on species within the family Pieridae (for example Makino et al., 1951; Mazokhin-Porshniakov, 1956; Nekrutenko, 1963; Obara \& Hidaki, 1967). Many genera in this family are characterized by the presence of highly conspicuous UV patterns particularly in the males (e.g. Colias and Gonepteryx), and various hypotheses have been put forward to explain them, such as species recognition (Silberglied \& Taylor, 1972, 1977) and sexual selection (Brunton \& Majerus, 1994).

In some genera of butterflies, there is a great deal of between-species variation in UV patterning. Closely related species (as evidenced by natural 
hybridization) may differ markedly in both visible and UV colours. One case in point is the presence or absence of UV in seemingly closely related species of the genus Colias. Silberglied \& Taylor (1972) first suggested that UV may be functioning as part of the system for reproductive isolation between two sympatric sister species, Colias eurytheme and $C$. philodice in the USA. Although the two species are, to our eyes, identical in terms of colour pattern, males of $C$. eurytheme exhibit a bright UV pattern on the dorsal surface of their wings whereas $C$. philodice males do not. Moreover, eurytheme males which had their UV patterns destroyed suffered a significant drop in the number of conspecific matings. Hence, a plausible explanation for the variation between the two species was that the UV trait evolved as part of a system of isolating mechanisms between sympatric species. In addition, a spectrometric analysis of the variation in UV patterns among European Colias suggested that, as well as species recognition, UV may be involved in sexual selection (Brunton \& Majerus, 1994).

Sexual traits are known to be highly variable (Young et al., 1993; Pomiankowski \& Møller, 1994) and through the process of sexual selection may be subject to continual change through time (Iwasa \& Pomiankowski, 1994). One result is that closely related species may sometimes appear very different in sexual traits but relatively similar in nonsexual morphology. This appears to be the case in some species of Colias. If UV traits originally evolved in response to some sort of inter- or intraspecific selection, one might expect the trait to appear or disappear frequently through time. If, however, there is some other explanation for why UV traits evolved, in response to environmental selection for example, then a different pattern of relationships would be expected. This hypothesis can be tested by looking at the phylogenetic relationships of the butterflies.

Most phylogenies in Lepidoptera have been constructed using morphological criteria and the Pieridae has, for a long time, been a confusing family. It is generally thought that, given the difficulties with Lepidopteran classification, the most productive source of alternative information is from molecular studies (Jong et al., 1995). I therefore used mitochondrial DNA sequences from part of the Cytochrome Oxidase subunit block I (CO I) to construct a phylogeny of the 12 recognized European Colias species. In addition to the questions concerning UV patterns, a molecular phylogeny will also shed light on the relationships of the different species within a notoriously complex group, the frequent hybridization that occurs between some of them, and their radiation within Europe. For example, one can test the hypothesis that sympatric or parapatric species would be closely related, and that those species known to hybridize (e.g. Colias nastes werdandi and $C$. hecla sulitelma) would be sister species.

\section{Methods}

\section{Sampling}

Butterflies were collected directly or obtained from private collections. Details of the 12 European and one American Colias species used in the analysis are given in Table 1. Freshly caught insects were preserved in absolute ethanol for transportation back to the laboratory and then frozen. Older specimens from collections were already desiccated and DNA was extracted from the dry tissue. The sequences for comparative purposes are those of Gonepteryx rhamni and Pieris napi (related genera), and Manduca sexta (obtained from Gen-Bank: accession number MSU09843). Presence or absence of UV patterns was determined photographically (see Brunton etal., 1995 for a detailed description of techniques).

\section{DNA preparation, PCR amplification and sequencing}

Genomic DNA was extracted from the abdomens of single individuals by grinding frozen or dry tissue, resuspending it in $250 \mu \mathrm{L}$ digestion buffer $(100 \mathrm{~mm}$ Tris-HCL pH 8.0, $80 \mathrm{~mm}$ EDTA, 1\% SDS, $160 \mathrm{~mm}$ sucrose) and digesting it overnight with $2.5 \mu \mathrm{L}$ proteinase $\mathrm{K}$ (at a concentration of $5 \mathrm{mg} / \mathrm{mL}$ ) at $37^{\circ} \mathrm{C}$. The DNA was then purified by phenol-chloroform extraction and resuspended in $100 \mu \mathrm{L}$ sterile distilled water. Two oligonucleotide primers for the mitochondrial CO I block (derived from the R. G. Harrison Laboratory, Cornell University) were used for PCR amplification (5'-GGATCACCTGATATAGCATTCCC-3' and 5'-CCCGGTAAAATTAAAATATAAACTTC- $3^{\prime}$ ). Each PCR reaction of $50 \mu \mathrm{L}$ contained $1 \times\left(\mathrm{NH}_{4}\right)_{2} \mathrm{SO}_{4}$ buffer (Bioline), $5 \mathrm{mM} \mathrm{MgCl}_{2}, 1$ unit Taq polymerase (Bioline), $0.2 \mathrm{~mm}$ of each nucleotide (Pharmacia), $20 \mathrm{pmol}$ of each primer, and $0.5 \mu \mathrm{L} 10 \%$ genomic DNA. PCR cycles on a Hybaid Omnigene machine consisted of one cycle of denaturation at $94^{\circ} \mathrm{C}$ for $1 \mathrm{~min}$; 35 cycles at $94^{\circ} \mathrm{C}$ for $15 \mathrm{~s}, 54^{\circ} \mathrm{C}$ for $1 \mathrm{~min}$ and $72^{\circ} \mathrm{C}$ for $40 \mathrm{~s}$; one cycle at $94^{\circ} \mathrm{C}$ for $15 \mathrm{~s}, 54^{\circ} \mathrm{C}$ for $1 \mathrm{~min}$ and $72^{\circ} \mathrm{C}$ for $10 \mathrm{~min}$. The PCR products were run out on a one per cent agarose gel, and a product of

(c) The Genetical Society of Great Britain, Heredity, 80, 611-616. 
Table 1 Details of the 13 Colias species used in the phylogenetic analysis

\begin{tabular}{llllll}
\hline & & & Date & & \\
Code & Species (Colias) & Location & captured & Sex & UV \\
\hline Ceu & C. eurytheme & USA & $3 / 11 / 94$ & $\mathrm{M}$ & + \\
H76 & C. hecla sulitelma & Norway & $28 / 7 / 96$ & $\mathrm{M}$ & + \\
N1 & C. nastes werdandi & Sweden & $27 / 6 / 95$ & $\mathrm{~F}$ & - \\
CP1 & C. palaeno & Sweden & $29 / 7 / 95$ & $\mathrm{~F}$ & - \\
Cb1 & C. balcanica & Macedonia & 1994 & $\mathrm{M}$ & + \\
Cx12 & C. crocea & England & $11 / 95$ & $\mathrm{~F}$ & \pm \\
Cph1 & C. phicomone & Switzerland & $28 / 7 / 95$ & $\mathrm{M}$ & - \\
Ca13 & C. australis & France & $26 / 7 / 91$ & $\mathrm{M}$ & - \\
Chy1 & C. hyale & France & $4 / 5 / 92$ & $\mathrm{M}$ & - \\
CL9 & C. libanotica heldreichii & Greece & 1991 & $\mathrm{M}$ & + \\
CC5 & C. chrysotheme & Hungary & 1996 & larva & + \\
Ce3 & C. erate & Kyrgystan & $6 / 7 / 96$ & $\mathrm{M}$ & - \\
Cm1 & C. myrmidone & Romania & $3 / 6 / 96$ & $\mathrm{~F}$ & + \\
\hline & & & &
\end{tabular}

+ or - refers to the presence or absence of UV in the males of the species only (females do not show UV patterns in this genus); \pm indicates presence of UV on hind-wings only.

$\approx 420$ bp excised from the gel and purified using Prep-a-gene-clean kit (Biorad). This was then sequenced using cycle sequencing in the presence of dye-labelled terminators. The resultant products were visualized on an ABI automated sequencer. Both strands were sequenced completely using each original PCR primer in turn.

\section{Phylogenetic analyses}

Sequence data were aligned by eye and maximum parsimony and maximum likelihood analyses of sequence data were performed using PAUP version 3.0s (Swofford, 1990) and PHYLIP version 3.56c (Felsenstein, 1992) computer software packages, respectively.

\section{Results}

A block of 406 bases within the CO I gene was successfully amplified for each individual and aligned by eye (data available on request). Eightytwo of the 406 nucleotide positions $(20 \%)$ were variable and phylogenetically informative. Fifty-eight of these were third codon positions, 17 were second and seven were first. A and T made up $68 \%$ of all haplotypes. The transition/transversion ratio was estimated to be 0.9 using the Quartet Puzzling program, PUZzLE (Strimmer \& Haesler, 1995), and rate variation was estimated by creating distance matrices (using the programme DNADIST with the maximum likelihood option and a ts/tv ratio of 0.9 ) for each codon position and calculating the mean of the pairwise distances within each matrix. The rates relative to the second position were $0.5: 1: 5$.

The parsimony analysis produced a single shortest tree of 253 steps and both parsimony and maximum likelihood methods produced the same tree topology, increasing overall confidence in the robustness of the trees. The maximum likelihood tree (Fig. 1), however, was significantly better according to the Kishino-Hasegawa-Templeton test (difference in $\ln$ $\mathrm{L}=-43.34466, \mathrm{SD}=10.131$ ) (Kishino \& Hasgawa, 1988). The tree supports a monophyletic origin of all the 12 European species and separates the American $C$. eurytheme. The European species can be subdivided further into three groups which correspond broadly to geography: three Scandinavian species, four central/east European species (Macedonia, Romania to Kyrgystan) and five central/west European species (Hungary, Greece, Switzerland, France).

The presence $(\mathrm{UV}+)$ or absence $(\mathrm{UV}-$ ) of UV reflection patterns is widespread throughout. If $\mathrm{UV}+$ were the ancestral state, then there have been at least four losses of the trait, with a minimum of one in each group. If UV- were the ancestral state then there must have been at least five changes. According to parsimony theory therefore UV+ appears as the ancestral state in the European group. But, in view of the number of switches from $\mathrm{UV}+$ to UV - in the phylogeny and the fact that 


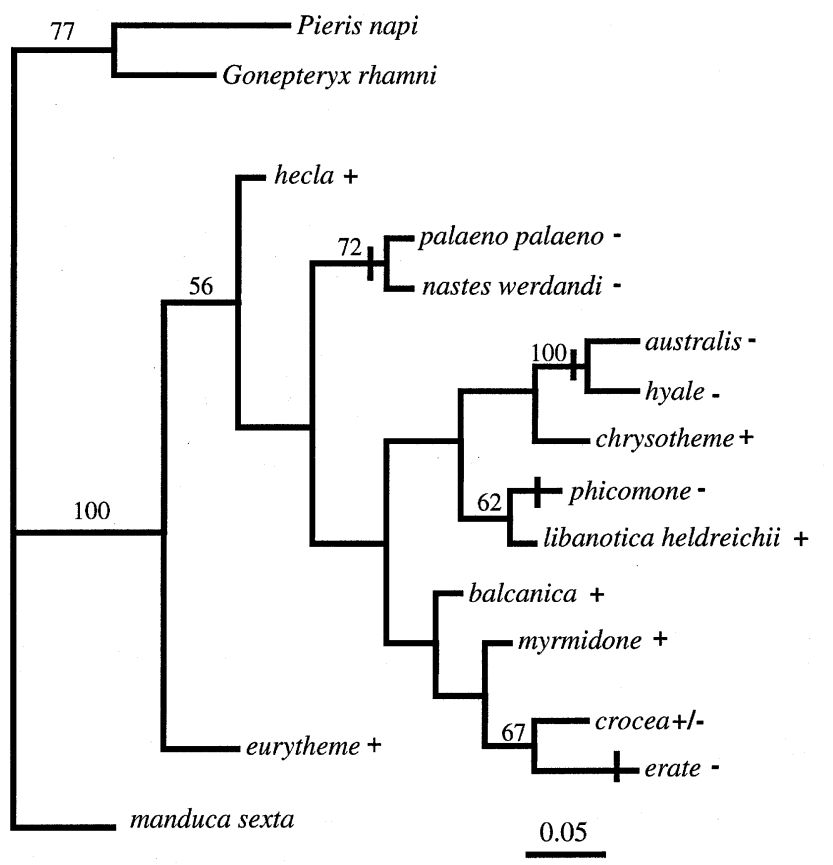

the outgroup is probably also polymorphic (sister species of $C$. eurytheme is $\mathrm{UV}-$ ) this result is merely suggestive.

A Kimura two-parameter model (Kimura, 1979) was used for calculating the substitution rates (Table 2).

\section{Discussion}

The mitochondrial DNA phylogeny for the European Colias divides them into three monophyletic
Fig. 1 Maximum-likelihood tree for 13 species of Colias and three outgroups. The tree that best described the data (ln likelihood $=-1737.92864$ ) was produced using a transition/transversion ratio of 0.9 , a rate variation relative to second codon positions of $0.5: 1: 5$, global rearrangements and randomizing sequence order five times. Bootstrap values per 100 replications were calculated from Jin/Nei distances with a coefficient of variation of 1.138 and the Fitch-Margolish method of tree construction (programs SEQBOOT, DNADIST, FITCH and CONSENSE). Only confidence values above $50 \%$ are shown. Branch lengths are proportional to the scale given in substitutions per nucleotide. + or indicates the presence or absence of UV reflection, respectively. A vertical line bisecting a branch shows where $\mathrm{UV}+$ has been lost.

Table 2 Nucleotide divergence values calculated using PHYLIP according to the two-parameter model of Kimura (1979)

\begin{tabular}{|c|c|c|c|c|c|c|c|c|c|c|c|c|c|c|c|}
\hline & mand & Pn59 & $\mathrm{R} 1$ & Ceu & H76 & $\mathrm{N} 1$ & $\mathrm{CP} 1$ & $\mathrm{Cb} 1$ & $\mathrm{Cx} 12$ & Cph1 & Ca13 & Chy1 & CL9 & CC5 & $\mathrm{Ce} 3$ \\
\hline Pn59 & 0.1982 & & & & & & & & & & & & & & \\
\hline R1 & 0.1477 & 0.1643 & & & & & & & & & & & & & \\
\hline Ceu & 0.1822 & 0.2647 & 0.2015 & & & & & & & & & & & & \\
\hline $\mathrm{H} 76$ & 0.1645 & 0.2077 & 0.1802 & 0.0636 & & & & & & & & & & & \\
\hline N1 & 0.1887 & 0.2376 & 0.2001 & 0.0730 & 0.0210 & & & & & & & & & & \\
\hline CP1 & 0.1786 & 0.2269 & 0.1898 & 0.0700 & 0.0210 & 0.0077 & & & & & & & & & \\
\hline $\mathrm{Cb} 1$ & 0.1770 & 0.2252 & 0.1956 & 0.0669 & 0.0209 & 0.0182 & 0.0156 & & & & & & & & \\
\hline Cx12 & 0.1967 & 0.2394 & 0.2187 & 0.0962 & 0.0581 & 0.0464 & 0.0554 & 0.0376 & & & & & & & \\
\hline Cph1 & 0.2066 & 0.2397 & 0.1980 & 0.0915 & 0.0470 & 0.0353 & 0.0437 & 0.0382 & 0.0533 & & & & & & \\
\hline $\mathrm{Ca} 13$ & 0.1884 & 0.2316 & 0.2011 & 0.1172 & 0.0672 & 0.0700 & 0.0642 & 0.0607 & 0.0680 & 0.0716 & & & & & \\
\hline Chy1 & 0.1909 & 0.2292 & 0.2014 & 0.1078 & 0.0677 & 0.0612 & 0.0646 & 0.0610 & 0.0739 & 0.0772 & 0.0380 & & & & \\
\hline CL9 & 0.1922 & 0.2457 & 0.2162 & 0.0883 & 0.0317 & 0.0206 & 0.0234 & 0.0234 & 0.0547 & 0.0297 & 0.0754 & 0.0726 & & & \\
\hline CC5 & 0.2220 & 0.2559 & 0.2165 & 0.1167 & 0.0563 & 0.0591 & 0.0538 & 0.0505 & 0.0752 & 0.0734 & 0.0812 & 0.0850 & 0.0587 & & \\
\hline $\mathrm{Ce} 3$ & 0.2404 & 0.2805 & 0.2447 & 0.1258 & 0.0857 & 0.0923 & 0.0864 & 0.0735 & 0.0655 & 0.1026 & 0.1172 & 0.1329 & 0.0917 & 0.0994 & \\
\hline $\mathrm{Cm} 1$ & 0.1901 & 0.2443 & 0.1986 & 0.0764 & 0.0291 & 0.0292 & 0.0238 & 0.0078 & 0.0440 & 0.0446 & 0.0612 & 0.0742 & 0.0344 & 0.0535 & 0.0674 \\
\hline
\end{tabular}

Codes are as in Table 1. mand, Manduca sexta; Pn59, Pieris napi; R1, Gonepteryx rhamni.

(c) The Genetical Society of Great Britain, Heredity, 80, 611-616. 
Hargreaves, 1982). From Scandinavia they have radiated south and east to the rest of Europe forming the other nine species.

The pattern of UV + and UV - is polyphyletic and hence compatible with that expected from a trait which is under intraspecific or interspecific selection (Young et al., 1993; Iwasa \& Pomiankowski, 1994). One species in a closely related pair may have a UV reflectance pattern whereas in the sister species it has been lost (e.g. C. phicomone and $C$. libanotica heldreichii or $C$. crocea and $C$. erate). If UV had evolved (or been lost) as an adaptive response to some environmental or ecological selection pressure, this pattern would be less likely. Instead, one might expect that all the species in the east European group would show a similar type of patterning, for example. Clearly this is not the case.

Within the genus Colias, there is often frequent hybridization between closely related species, particularly where those species are sympatric. The philodice/eurytheme example mentioned previously is a much quoted case in point, but there are other well documented examples. In Scandinavian Lapland, Colias nastes and $C$. hecla regularly hybridize in areas where the two species emerge and fly together, producing a form known as christiernssoni Lampa (Henriksen \& Kreutzer, 1981). Regardless of which method one uses to define a species, those groups which naturally hybridize are expected to be very closely related (sister species) and $C$. hecla and $C$. nastes were no exception to this view. However, assuming that the gene tree is a true representation of the species tree, the phylogeny reveals that $C$. palaeno, rather than $C$. hecla, is the closest relative of $C$. nastes. Hybridization probably does not occur between nastes and palaeno because their habitat and larval food plants differ significantly, so they simply do not meet. In contrast, hecla and nastes do frequently meet and share similar habitats and foodplants, thereby making hybridization more likely.

In accordance with some other phylogenetic studies (e.g. Juan et al., 1995; Brunton \& Hurst, in press) there is a discrepancy between the mtDNA phylogeny and morphological taxonomy. This is illustrated by the two allopatric species, C. phicomone and $C$. nastes, which are, phenetically, almost identical and can often only be distinguished by locality (Higgins \& Hargreaves, 1982). They inhabit similar mountainous habitats in northern Lapland (C. nastes) and the Alps and Pyrenees (C. phicomone). Their ecology and phenotype suggests that they should be closely related and one hypothesis to account for their geographical separation was that it corresponded to the retreat of the last ice-age.
However, the DNA phylogeny indicates that they are not closely related. Thus, other mechanisms explaining their phenotypic similarity (e.g. adaptation to similar environments) should perhaps be considered.

In summary, the molecular phylogeny indicates that, within the genus Colias, the Scandinavian species are the oldest in Europe and from there they have radiated south and east forming nine species which fall into two monophyletic clades, a central/ west clade of five species and a central/east clade of four species. UV reflectance is polyphyletic and thus consistent with a pattern expected from a trait evolving in response to some form of species recognition or sexual selection. As such, it is also likely to have been an important factor in the speciation of the group.

\section{Acknow ledgements}

I thank Håken Elmquist, Ruth Feber, Martin Gascoigne-Pees, Sergiu Mihut, Peter Russell and Bob Worthy for kindly providing some of the butterflies. Greg Hurst gave help and advice in the laboratory and Laurence Hurst, Michael Majerus, Yoshiaki Obara and Alec Panchen read and commented on the manuscript. The text was also greatly improved by the comments of two anonymous referees. This work was financed by a grant from the Natural Environmental Research Council (ref. GR9/01664).

\section{References}

BENNetT, A. T. D., CUTHILl, I. C. AND NORRIS, K. J. 1994. Sexual selection and the mismeasure of color. Am. Nat., 144, 848-860.

BENNETT, A. T. D., CUTHILl, I. C., PARTRIDGe, J. C. AND MAIER, E. J. 1996. Ultraviolet vision and mate choice in zebra finches. Nature, 380, 433-435.

BRUNTON, C. F. A. AND HURST, G. D. D. 1998. Mitochondrial DNA phylogeny of Brimstone butterflies (genus Gonepteryx) from the Canary Islands and Madeira. Biol. J. Linn.Soc., 63, 69-79.

BRUNTON, C. F. A. AND MAJERUS, M. E. N. 1995. Ultraviolet colours in butterflies: intra- or inter-specific communication? Proc. R. Soc. B., 260, 199-204.

BRUNTON, C. F. A., RUSSELl, P. J. C. AND MAJERUS, M. E. N. 1996. Variation in ultraviolet wing patterns of brimstone butterflies (Gonepteryx: Pieridae) from Madeira and the Canary Islands. Entomologist, 115, 30-39.

BURKHARDT, D. 1989. UV vision: a bird's eye view of feathers. J. Comp. Physiol. A, 164, 787-796.

FELSENSTEIN, J. 1993. PHYLIP (phylogenetic inference package) version $3.56 \mathrm{c}$. University of Washington, Seattle. 
FLEISHMAN, L. J. E., LOEWS, R. AND LEAL, M. 1993. Ultraviolet vision in lizards. Nature, $\mathbf{3 6 5}, 397$.

HENRIKSEN, H. J. AND KREUTZER, I. B. 1982. The Butterflies of Scandinavia in Nature. Skandinavisk Bogforlag, Odense.

HIGgINS, L. G. AND HARGREAVES, B. 1983. The Butterflies of Britain and Europe. Collins, London.

IWASA, Y. AND POMIANKOWSKI, A. 1995. Continual change in mate preferences. Nature, 377, 420-422.

JACOBS, G. H. 1992. Ultraviolet vision in vertebrates. Am. Zool., 32, 544-554.

JONG, R. D., VANE-WRIGHT, R. I. AND ACKERY, P. R. 1996. The higher classification of butterflies (Lepidoptera): problems and prospects. Ent. Scand., 27, 65-101.

JUAN, C., IBRAHIM, K. M., OROMÍ, P. AND HEWITT, G. M. 1996. Mitochondrial DNA sequence variation and phylogeography of Pimelia darkling beetles on the Island of Tenerife (Canary Islands). Heredity, 77, 589-598.

KIMURA, M. 1980. A simple method for estimating evolutionary rate of base substitution through comparative studies of nucleotide sequences. J. Mol. Evol., 16, $111-120$.

KISHINO, H. AND HASGAWA, M. 1989. Evaluation of the maximum likelihood estimate of the evolutionary tree topologies from DNA sequence data, and the branching order in Hominoidea. J. Mol. Evol., 29, 170-179.

LUTZ, F. E. 1933. 'Invisible colours' of flowers and butterflies. Natural History, 33, 565-576.

MAKINO, K., SATCH, M., KOIKE, M. AND UENO, N. 1952. Sex in Pieris rapae L. and the pteridin content of their wings. Nature, 170, 933-934.
MAZOKHIN-PORSHNIAKOV, G. A. 1957. Reflecting properties of butterfly wings and role of ultra-violet rays in the vision of insects. Biofizika, 2, 352-362.

MENZEL, R. AND BACKHAUS, W. 1991. Colour vision in insects. In: Gouras, P. (ed.) The Perception of Colour, pp. 262-293. CRC Press, Boca Raton, FL.

NEKRUTENKO, Y. P. 1964. The hidden wing-pattern of some Palearctic species of Gonepteryx and its taxonomic value. J. Res. Lepidopt., 3, 65-68.

OBARA, Y. AND HIDAKI, T. 1968. Recognition of the female by the male, on the basis of ultra-violet reflection, in the white cabbage butterfly, Pieris rapae crucivora Boisduval. Proc. Japan Acad., 44, 829-832.

POMIANKOWSKI, A. AND MØLLER, A. P. 1995. A resolution of the lek paradox. Proc. R. Soc. B., 260, 21-29.

SILBERGLIED, R. E. AND TAYLOR, O. R. 1973. Ultra-violet differences between the sulphur butterflies Colias eurytheme and $C$. philodice and a possible isolating mechanism. Nature, 241, 406-408.

SILBERGLIED, R. E. AND TAYLOR, O. R. 1978. Ultra-violet reflection and its behavioural role in the courtship of the sulphur butterflies Colias erytheme and $C$. philodice. Behav. Ecol. Sociobiol., 3, 203-243.

STRIMMER, K. AND HAESLER, A. v. 1996. Quartet Puzzling - a quartet maximum likelihood method for reconstructing tree topologies. Mol. Biol. Evol., 13, 964-969.

SWOFFORD, D. L. 1991. PAUP version 3.0s. Illinois Natural History Survey, Champaign, IL.

YOUNG, J. R., HUPP, J. W., BRADBURY, J. W. AND BRAUN, C. E. 1994. Phenotypic divergence of secondary sexual traits among sage grouse, Centrocercus urophasianus, populations. Anim. Behav., 47, 1353-1362. 